\title{
PROBABLE MORTALITY OF Holothuria (Halodeima) grisea (SELENKA, 1867) (ECHINODERMATA, HOLOTHUROIDEA) AFTER ACUTE IMPACT OF OIL SPILL IN THE NORTHEAST OF BRAZIL IN 2019
}

\author{
Provável mortalidade de Holothuria (Halodeima) grisea \\ (Selenka,1867) (Echinodermata, Holothuroidea) após impacto agudo \\ do derramamento de petróleo no Nordeste brasileiro em 2019
}

\author{
Walter Ramos Pinto Cerqueira* \\ * Universidade Estadual de Feira de Santana, Departamento de Ciências Zoológicas, \\ Museu de Zoologia, Divisão de Invertebrados Aquáticos. E-mail: walter@uefs.br
}

\begin{abstract}
The Brazilian northeastern coast suffered in 2019 the greatest acute impact of oil in the country's history, with all states in the region being affected by extra-heavy oil. Holothuria (Halodeima) grisea is a detritivorous holoturoid, which ingests sediment to feed, and can passively ingest oil from spills existing in the sediment. To investigate the occurrence of oil in the intestinal content of $H$. (H.) grisea, a N of 20 individuals was collected on the Salvador coast (BA) in October 2019 between the coordinates $12^{\circ} 57^{\prime} \mathrm{S} / 38^{\circ} 20^{\prime} \mathrm{W}$. Of this total, 10 individuals were found dead in the environment and 10 collected alive, for comparison purposes. Of the individuals found dead, $40 \%$ were eviscerated (without intestines) and it was not possible to carry out content analysis. Of the 6 remaining dead individuals, $67 \%$ had oil in their intestinal contents. For the 10 live sea cucumbers collected, none was eviscerated and all had a full intestine, with oil being observed in the intestinal content of 1 specimen (10\%). The $\chi 2$ test confirmed with a of 0.025 the possible relationship between oil and the mortality of $H$. (H.) grisea, demonstrating that the acute oil spill probably was lethal for this species on the northeastern coast of Brazil.
\end{abstract}

Keywords: sea cucumber, hydrocarbons, PAHs.

Recebido em: 20/03/2020

Aprovado em: 06/10/2020

Publicado online em: 20/05/2021 


\section{RESUMO}

A costa nordestina brasileira sofreu no ano de 2019 o maior impacto agudo de petróleo da história do país, com todos os estados da região sendo afetados por óleo extrapesado. Holothuria (Halodeima) grisea é um holoturoide detritívoro que ingere sedimento, podendo engolir de forma passiva petróleo oriundo de derramamentos existente no sedimento. Para investigar a ocorrência de petróleo no conteúdo intestinal de $H$. (H.) grisea foi coletado um $\mathrm{N}$ de 20 indivíduos no litoral de Salvador (BA) no mês de outubro de 2019 entre as coordenadas $12^{\circ} 57^{\prime} S$ e $38^{\circ} 20^{\prime} \mathrm{W}$. Desse total, 10 indivíduos foram encontrados mortos no ambiente e 10 coletados vivos, para fins de comparação. Dos indivíduos encontrados mortos, $40 \%$ estavam eviscerados (sem intestino), não sendo possivel fazer as análises de conteúdo. Dos 6 indivíduos mortos restantes, 67\% apresentaram petróleo no conteúdo intestinal. Para as 10 holotúrias coletadas vivas, nenhuma estava eviscerada e todas estavam com o intestino cheio, sendo observado petróleo no conteúdo intestinal de um espécime (10\%). O teste do X2 confirmou com a de 0,025 a possível relação do petróleo com a mortalidade de H. (H.) grisea, demonstrando que o derramamento agudo de óleo provavelmente foi letal para essa espécie na costa nordeste do Brasil.

Palavras-chave: pepino-do-mar, hidrocarbonetos, HPAs.

\section{INTRODUCTION}

Petroleum activity in the marineenvironment can cause several types of environmental impacts such as habitat degradation, which is one of the main factors that cause the reduction of the planet's biodiversity (Gomes; Palma \& Silva, 2000; Martins et al., 2015). At the end of August 2019, a large amount of crude oil began to appear in Paraíba coast and by the end of December hundreds of tons were recorded in practically all municipalities on the northeastern coast, reaching, on a much smaller and non-impacting scale, few locations in the states of Espírito Santo and Rio de Janeiro located in the southeastern region (Araújo; Ramalho \& Melo, 2020; Carmo \& Teixeira, 2020), which is undoubtedly the greatest environmental tragedy ever observed on the northeastern coast of Brazil, causing several social, economic and ecosystems losses (Araújo; Ramalho \& Melo, 2020; Soares et al., 2020b; Soares et al., 2020a).

Crude oil is a mix of polycyclic aromatic hydrocarbons (PAHs), volatile organic compounds (VOCs), hydrogen sulfide and several metals trace, which can poison the organisms in an acute and chronic way, mainly the toxic fractions of oil associated with the aromatics compounds, which can kill by intoxication (Blackburn et al., 2014; Lourenço et al., 2020; Pena et al., 2020). In relation to PAHs pollution in aquatic environments, accidents with oil spills are among the most severe for benthic invertebrates, causing toxic effects such as embryonic abnormalities and immunotoxicity (Honda \& Suzuki, 2020), mechanical effects such as asphyxiation by clogging respiratory structures, and bioecological effects such as impacts on growth, food and disturbances in the food web (Blackburn et al., 2014). Considering that crude oil can settle and become encrust in rocks in coastal environments, its effects on benthic communities can be fatal.

The sea cucumber Holothuria (Halodeima) grisea is a deposit-eating species and can act in the marine environment as a mitigating agent for environmental damage due to its 
consuming character of organic material and recycling the sediment contributing to the textural and geo-environmental characteristics of the areas where it occurs, among them the base and cracks of the intertidal region rocks (Costa, 2010; Sousa, 2014). Despite being a very common species on the northeastern beaches, there is a knowledge gap regarding the biology and ecology of H. (H.) grisea (Sousa, 2014). Due to ingesting sediment to feed, this sea cucumber can be passively contaminated by swallowing oil from spills existing in the sediment. However, there is no information in the scientific literature on this subject for $H$. (H.) grisea or other species of sea cucumbers.

In the course of voluntary beach cleaning work in Salvador during the acute impact of the oil spill in October 2019, several specimens of dead invertebrates were found on the beaches, including specimens of $H$. $(H$.) grisea. Mass mortality events of benthic organisms after acute impacts from oil spills have been known for a long time, where in a few days it is possible to see individuals from different phyla dead and dying on the beaches (Nadeau \& Bergquist, 1977).

Aiming to gather information about the effects of the spill on sea cucumbers, this study aimed to verify the presence of crude oil in the intestinal content of $H$. (H.) grisea and if this presence, when observed, was related to the mortality of this species after the acute impact that hit the Brazilian northeast in 2019.

\section{MATERIAL AND METHODS}

To investigate the occurrence of oil in the intestinal content of $H$. (H.) grisea, a $\mathrm{N}$ of 20 individuals was collected on the coast of Salvador (BA) in October 2019, in the stretch between the beaches of Pedra do Sal (12 $57^{\prime} 9.49^{\prime \prime}$ S/38 $20^{\prime} 45.82^{\prime \prime}$ W) and Itapuã Lighthouse (12 57'26.24" S/38²1'13.49" W) (Figure 1).

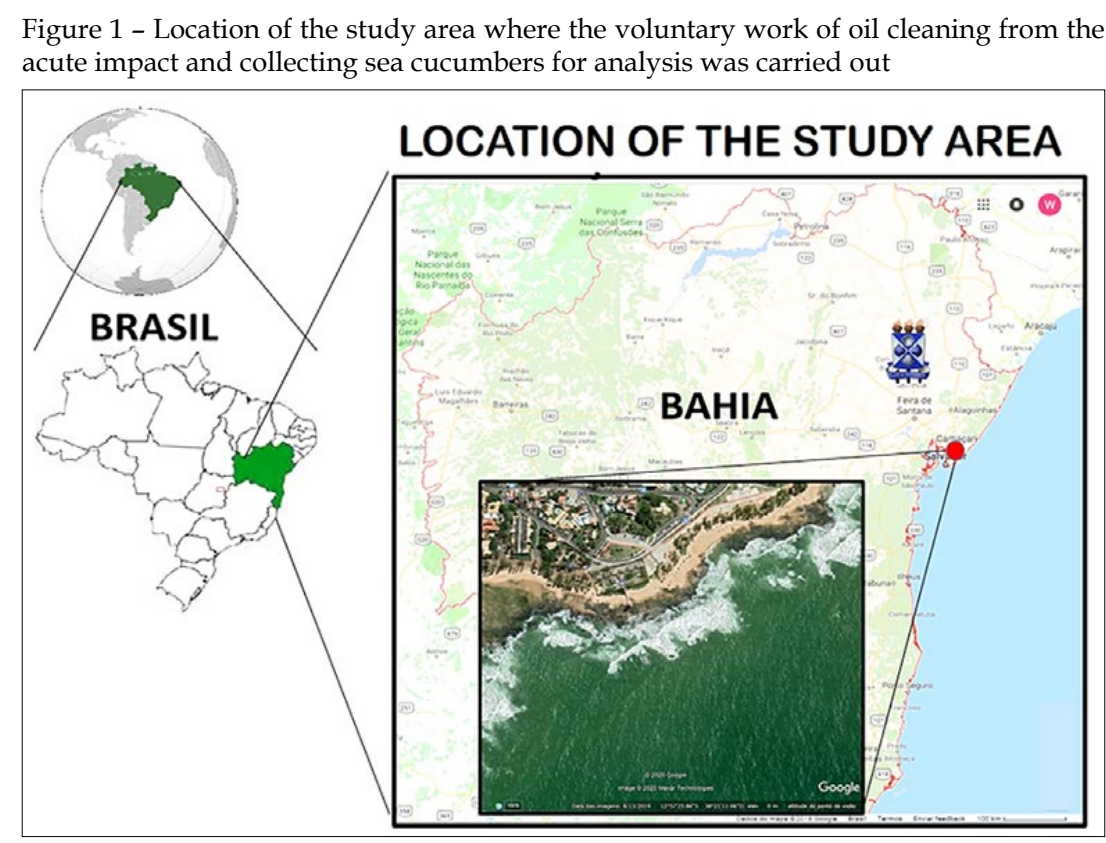

Were collected 10 individuals found dead in the environment (group 1) to check the presence of crude oil in the intestinal tract and, in the same stretch, 10 live and visually 
healthy individuals (group 2) to compare the food contents in each group. The live animals were anesthetized in fresh water before the dissection procedures, placed in individual containers, so as not to lose the intestinal contents that could be eliminated through the feces during the anesthesia process; the animals found dead in the field were opened directly for necropsy, performed under a stereoscopic microscope in the laboratory. The sediment of the intestinal contents was analyzed, registering, when present, the oil in the samples.

In order to know the percentage of oil in relation to the rest of the intestinal content, the content was dried at room temperature, weighed on an analytical balance to know the total weight and then the oil was manually separated from the sediment, with the aid of tweezers and stylets, weighing this fraction on an analytical balance.

To check the relationship between the presence of oil found in the intestinal content and the mortality of sea cucumbers, the $\chi^{2}$ test was used.

\section{RESULTS}

Of the 10 individuals found dead on the beaches, 4 (40\%) were eviscerated (without intestines) and it was not possible to carry out intestinal content analyzes. Of the 6 remaining dead individuals, $4(67 \%)$ had oil in the intestinal content sediment. For the 10 live sea cucumbers collected, none were eviscerated and all had a full intestine, with oil being observed in the intestinal contents of only 1 specimen (10\%) (Figure 2).

Figure 2 - Percentage values of eviscerated individuals, with and without oil in the intestinal content of sea cucumber Holothuria (Halodeima) grisea found dead and in specimens collected alive during the acute impact of the oil spill in the northeast in 2019

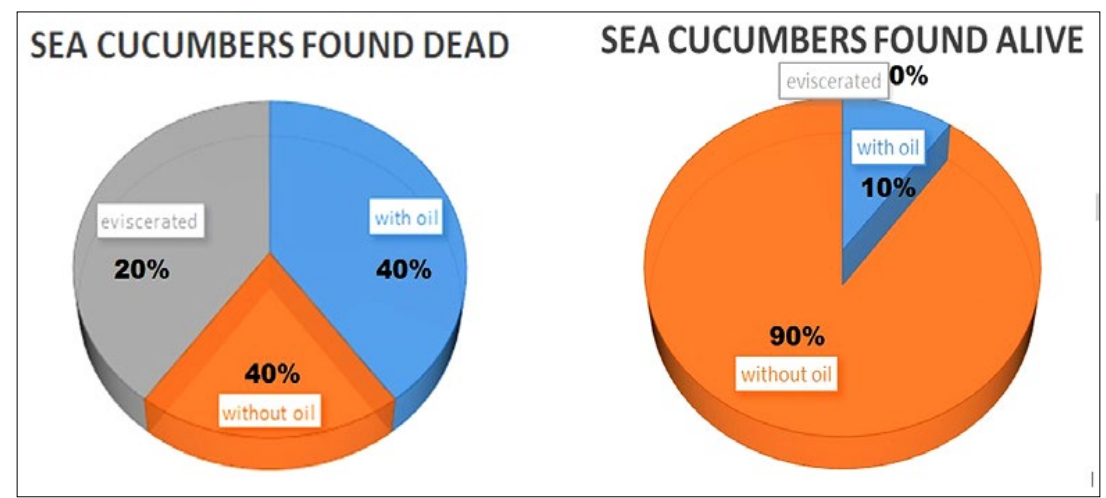

In percentage terms, large amounts of oil were not found in the intestinal contents of both the dead and live collected sea cucumbers, whose oil percentage ranged from 2 to $10 \%$ by weight of the total intestinal content (Figure 3).

Analyzing the observed and expected values of dead and live sea cucumber with and without oil in the intestinal content, the $\chi^{2}$ test rejected the null hypothesis and accepted the hypothesis that there is a relationship between the presence of oil in the intestinal content and the mortality of Holothuria (Halodeima) grisea $\left(x^{2}=5.57, \alpha=0.025,1\right.$ degree of freedom) (Table I). 
Figure 3 - Fraction of oil (\%) in the intestinal content (sediment) of dead and live sea cucumber Holothuria (Halodeima) grisea during the acute impact of the oil spill in the northeast in 2019. Eviscerated specimens (without intestine) were taken from this analysis

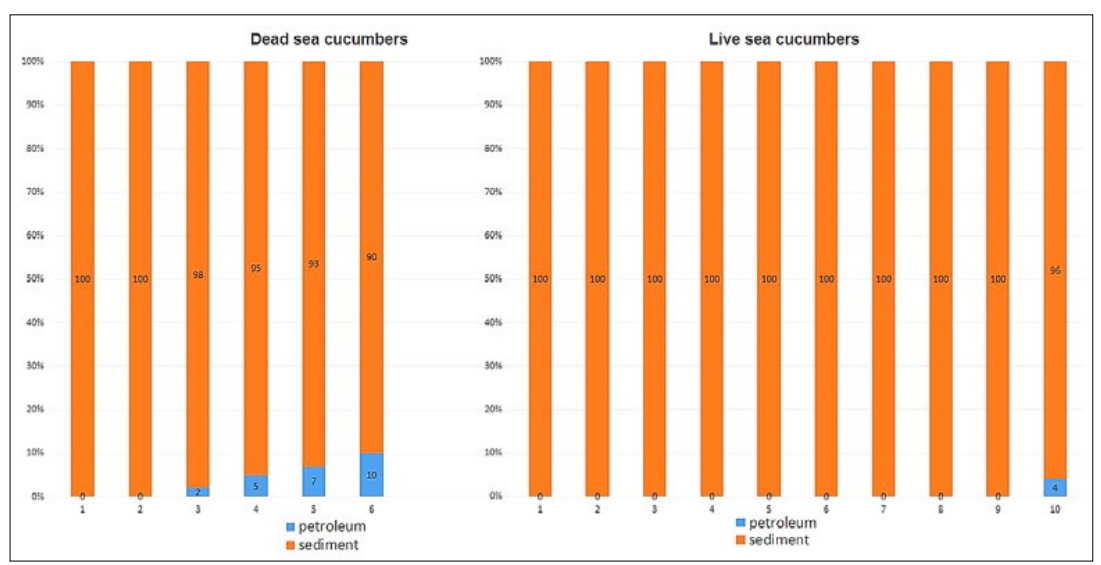

Table I - Observed and expected values of Holothuria (Halodeima) grisea dead and alive and with and without presence of oil in the intestinal content. Eviscerated specimens (without intestines) were removed from this analysis

\begin{tabular}{l|c|c|c}
\hline Holothuria (Halodeima) grisea - observed values & \multicolumn{1}{l}{ Alive } & TOTAL \\
\hline With oil in the intestinal content & 4 & 1 & 11 \\
\hline Without oil in the intestinal content & 2 & 9 & 16 \\
\hline \multicolumn{1}{c|}{ TOTAL } & 6 & 10 & TOTAL \\
\hline Holothuria (Halodeima) grisea - expected values & Deads & 3,12 & 5 \\
\hline With oil in the intestinal content & 1,88 & 6,88 & 11 \\
\hline Without oil in the intestinal content & 4,12 & 10 & 16 \\
\hline
\end{tabular}

\section{DISCUSSION}

The evisceration in sea cucumbers, as observed in this work, besides being a strategy to escape from predators is also a response to environmental stress caused by several factors, among them the sediment toxicity, which are contaminated after spill events as observed in the northeast of Brazil in 2019. Sediments with toxic pollutants are responsible for the mortality of several marine organisms (Blackburn et al., 2014; Honda \& Suzuki, 2020). Sediment pollution can cause physiological stress on sea cucumber that, under this condition, trigger a series of metabolic processes that culminate in evisceration (Hook et al., 2018; Hou et al., 2019). The evisceration would also work as a means of discarding harmful substances that cannot be excreted otherwise (Byrne, 1985). Taking as a premise the information presented, even though it is not possible to analyze the intestines of the eviscerated specimens of $H$. (H.) grisea, it can raise the hypothesis that the stress generated by the acute impact of the spill may have provoked defense reactions in the four individuals found dead and eviscerated on the beaches between Pedra do Sal and Farol de Itapuã in Salvador, however additional studies involving chemical, cytological and histological analyzes would be necessary to confirm this hypothesis. 
The levels of pollution by PAHs can be considered as low, moderate, high and very high when the concentrations of these in the sediment are from 0 to $100 \mathrm{ng}$ g- 1 of dry weight, 100-1000 ng g-1 of dry weight, 1000-5000 ng g-1 of dry weight and > $5000 \mathrm{ng}$ g-1 of dry weight respectively (Khazaali et al., 2016). Studies carried out on the northwest coast of the Atlantic Ocean considered extremely high concentrations of oil in marine sediment ranging between 11,3 and 2,900 $\mathrm{mg} / \mathrm{kg}$ (Tong et al., 1999), values that in proportional terms would be less than $1 \%$ of oil per kilo of sediment. Comparing this result to the oil percentages that were found in the sea cucumber intestinal tract sediment in the stretch between Pedra do Sal and Itapuã in Salvador (from 2 to 10\%), it is observed that the oil percentages in relation to the sediment were higher than the concentrations considered extremely high of oil for sediment in the environment described in the literature, which would have a direct relationship with the acute impact of the spill and with the mortality of individuals, considering that sea cucumbers are organisms sensitive to any (micro) contaminants accumulated in marine sediments (Kamyab et al., 2016). PAHs are bioavailable for marine organisms through the food chain, such as contaminated sediments, and the uptake of this pollutant depends on its bioavailability and the physiology of the organisms (Khazaali et al., 2016), which would explain the fact that two dead organisms without oil in the intestinal content and one, still alive and healthy, with oil in its food content. The observed and expected values of live and dead sea cucumbers with and without oil in their intestinal contents differed from the null hypothesis precisely because the PAHs have adverse effects on the physiology and metabolism of the sea cucumbers (Hook et al., 2018; Hou et al., 2019; Kamyab et al., 2016; Khazaali et al., 2016; Long et al., 1995), making evident in this study the likely lethal effect of large concentrations of oil arising from acute impacts on the species H. (H.) grisea.

\section{CONCLUSION}

Oil from the acute impact of the spill in northeastern Brazil in 2019 may have influenced the mortality of Holothuria (Halodeima) grisea compromising the biodiversity of the benthic marine fauna of the northeastern Brazil, however, additional studies involving oil concentrations and species mortality are needed for more conclusive results.

\section{REFERENCES}

Araújo, M.E.; Ramalho, C.W.N. \& Melo, P.W. Pescadores artesanais, consumidores e meio ambiente: consequências imediatas do derramamento de óleo em Pernambuco, Nordeste do Brasil. Cadernos de Saúde Pública, Rio de Janeiro, v. 36, n. 1, e00230319, 2020. Available in: http:/ / www.scielo.br/scielo.php?script=sci_arttext\&pid=S0102-311X2020 000100301\&tlng=en. Doi: 10.1590/0102-311X00230319.

Byrne, M. Evisceration behaviour and the seasonal incidence of evisceration in the holothurian Eupentacta quinquesemita (Selenka). Ophelia, v. 24, n. 2, p. 75-90, 1985.

Blackburn, M.; Mazzacano, C.A.S.; Fallon, C. \& Black, S. H. Oil in our oceans. A review of the impacts of oil spills on marine invertebrates. 152 p., 2014. Portland, OR: The Xerces Society for Invertebrate Conservation. Available in: https://xerces.org/wp-content/uploads/2014 /04/OillnOurOceans_XercesSoc_apr2014.pdf. 
Carmo, E.H. \& Teixeira, M.G. Desastres tecnológicos e emergências de saúde pública: o caso do derramamento de óleo no litoral do Brasil. Cad. Saúde Pública [online]. 2020, v.36, n. 2 [cited 2020-03-17], e00234419. Available in: http://www.scielo.br/scielo.php?script=sci_ arttext\&pid=S0102-311X2020000200502\&lng=en\&nrm=iso. Accessed on: Jan. 31, 2020. https://doi.org/10.1590/0102-311x00234419.

Gomes, A.S.; Palma J.J.C. \& Silva, C.G. Causas e consequências do impacto ambiental da exploração dos recursos minerais marinhos. Revista Brasileira de Geofísica, v. 18, n. 3, p. 447454, 2000.

Honda, M. \& Suzuki, N. Toxicities of polycyclic aromatic hydrocarbons for aquatic animals. Int. J. Environ. Res. Public Health, v. 17, n. 1363, p. 1-23, 2020. Doi:10.3390/ijerph17041363.

Hook, S.E.; Revillb, A.T.; Mondonc, J.; Corbettc, P.; Armstronga. E.K.; Songc, J.; Tannere, J.E.; Stalviesf, C.; Rossf. A.S. and Alan Williams. Naturally occurring hydrocarbon content and baseline condition of deep-sea benthic fauna from the Great Australian Bight. Deep-Sea Research Part II, v. 157-158, 2018, p. 106-120. https://doi.org/10.1016/j.dsr2.2018.08.005.

Hou, S.; Jin, Z.; Jiang, W.; Chi, L.; Xia, B. \& Chen, J. Physiological and immunological responses of sea cucumber Apostichopus japonicus during desiccation and subsequent resubmersion. PeerJ. 2019. 7:e7427. http://doi.org/10.7717/peerj.7427.

Kamyab, E.; Döring J.; Khazaali, A. \& Kunzmann, A. Polycyclic aromatic hydrocarbon pollution affects tissue fatty acid compositions in Holothuria scabra (Jaeger, 1833): A sea cucumber from Qeshm Island, Persian Gulf, Iran. Front. Mar. Sci. Conference Abstract: IMMR | International Meeting on Marine Research 2016. Doi: 10.3389/conf.FMARS.2016.04.00104.

Khazaali, A.; Kunzmann, A.; Bastami, K.D. \& Baniamam, M. Baseline of polycyclic aromatic hydrocarbons in the surface sediment and sea cucumbers (Holothuria leucospilota and Stichopus hermanni) in the northern parts of Persian Gulf. Marine Pollution Bulletin, v. 1, p. 539-545, 2016. Doi:10.1016/j.marpolbul.2016.05.039.

Long, E.R.; MacDonald, D.D.; Smith, S.L. \& Calder, F.D. Incidence of adverse biological effects within ranges of chemical concentrations in marine and estuarine sediments. $J$. Environ. Manag, v. 19, p. 18-97, 1995.

Lourenço et at. Mysterious oil spill along Brazil's northeast and southeast seabord (20192020): trying to find answers and filling data gaps. Marine Pollution Bulletin,156, 111219, 2020.

Martins, S.S.S.; Silva, M.P.; Azevedo, M.O. \& Silva, V.P. Produção de petróleo e impactos ambientais: algumas considerações. Holos, a. 31, v. 6, p. 54-76, 2015. Doi: 10.15628/ holos.2015.2201.

Nadeau, R.J. \& Bergquist, E.T. Effects of the march 18, 1973 oil spill near Cabo Rojo, Puerto Rico on tropical marine communities. International Oil Spill Conference, Proceedings: March 1977, v. 1977, n. 1, p. 535-538, 1977.

Pena, P.G.L.; Northcross, A.L.; Lima, M.A.G. \& Rêgo, R.C.F. Derramamento de óleo bruto na costa brasileira em 2019: emergência em saúde pública em questão. Cadernos de Saúde Pública, Rio de Janeiro, v. 36, n. 2, e00231019, 2020. Available in: http:/ /www.scielo.br/ scielo.php?script=sci_arttext\&pid=S0102-311X2020000200501\&tlng=pt. Doi: 10.1590/0102 $-311 \times 00231019$. 
Soares, M. de O.; Teixeira, C.E.P.; Bezerra, L.E.A.; Rossi, S.; Tavares, T. \& Cavalcante, R.M. Brazil oil spill response: time for coordination. Science, v. 367, n. 6474, p. 155, 2020a. Doi: 10.1126/science.aaz9993.

Soares, M. de O.; Teixeira, C.E.P.; Bezerra, L.E.A. \& Paiva, S. Oil spill in South Atlantic (Brazil): environmental and governmental disaster. Marine Policy, 115, 103879. 2020b.

Sousa, S.T. Caracteristicas texturais e geoambientais das áreas de ocorrência do pepino do mar, Holothuria grisea (Equinodermata: Holothuroidea), Bitupitá-Ceará. Revista GeoUECE - Programa de Pós-Graduação em Geografia da UECE Fortaleza/CE, v. 3, n. 5, p. 235-237, jul./ dez. 2014. Available in: http:// seer.uece.br/geouece.

Tong, S.L.; Goh, S.H.; Abdulah, A.R.; Tahir, N.M. \& Wang, C.W. Asean marine water quality criteria for oil and grease. Marine Environment Division, Water Quality Management Bureau, Pollution Control Department, 1999. 28 p. 